$$
\begin{aligned}
& \mathrm{SF}_{258} \\
& \mathrm{~W}_{3} \mathrm{M}_{2}
\end{aligned}
$$


During the summer of 1906, notwithstanding the completion of, and the satisfactory results obtained from, the Washington filtration works, it was found, contrary to the general expectation, that there was no diminution in the prevalence of typhoid fever. Owing to the limited force of inspectors under the health officers and the entire absence of a bacteriologic laboratory under his control, no extended investigation into the causation of this condition could be conducted. Consequently, in June, 1906, the District Commissioners requested the aid of the Bureau of Public Health and Marine-Hospital Service toward solving this problem. The work of the bureau covered the conditions that existed within the limits of the District. Very early in the course of the investigations attention was forcibly drawn to the milk supply. A summary of work done was submitted to the District Commissioners in March last. Ten per cent. of the cases of typhoid fever examined were directly traced to milk infection. The study of the methods of receiving, handling, caring for and distributing milk showed a most deplorable state of affairs. This will be shown in great detail in the full report which is to be issued shortly.

On June 6, 1894, I, as chairman of a committee, presented a report on typhoid fever in the District of $\mathrm{Co}-$ lumbia to the medical society of the district. This report was afterward presented to the district committees of both houses of Congress and was printed as a public document. While preparing this report the many insanitary conditions connected with the milk supply were

\footnotetext{
* Read in the Section on Hygiene and Sanitary Science of the American Medical Association, at the Fifty-eighth Annual Session,
} 
noticed. "Contaminated mill" was mentioned as a prominent cause of the disease. Among the recommendations of this committee which were unanimously adopted by the society were: "The construction of works for the filtration of the Potomac water, the only proper method of purification; the abandonment of all wells as rapidly as possible within the city limits. Careful purification and inspection of all dairies in the District from which the milk supply is drawn; and the enactment of a law whereby no milk shall be sold in the District without a permit from the health office. The inspection should cover an examination at the dairies of all possible sources of infection, including the water supply."

Early in September, 1906, I had a conference with the Hon. James Wilson, the Secretary of Agriculture, and discussed with him the insanitary conditions that had been observed on dairy farms, as well as the numerous reports of contaminated waters, as shown by repeated chemical analyses. The advisability was urged of carrying out the recommendation as to dairy farms made by the committee of the medical society in 1894 .

$\therefore \quad$ : Repeated examinations of the milk supply in a number of states and the general conditions surrounding the same have been made by the Department of Agriculture. The Secretary immediately took great interest in the subject. Fully appreciating that a study of the sources of supply would be of great value, he directed that careful and thorough inspection should be made of every source of supply of milk to the city from the District of Columbia, Maryland and Virginia.

The results as obtained were from time to time reported. Most astounding conditions were found to exist. Especially interesting were the bacteriologic investigations of the water supply of sixty dairy farms, which were made by the Department of Agriculture in November and December, taken without selection in Maryland, Virginia and the District of Columbia. These showed that but 25 per cent. were under the danger line, considering that 500 bacteria to the cubic centimeter, when uncontaminated with sewage bacteria, is the limit of perfect safety; twenty-seven showed the presence of bacillus coli-45 per cent. A number of wells or springs examined contained over 20,000 bacteria to the crbic centimeter; one contained $2 \%, 200$. 
Two cases of fever were in actual existence on two farms at the time of the examination of the water supply, one in Maryland and one in Virginia.

This knowledge, in the light of the recent reports of Dr. Schroeder showing the presence of the tubercle bacillus in the feces of cows and those of Dr. Soper as to the presence of the typhoid bacillus in the feces of a patient, demands that greater attention should be paid to water supplies showing the colon bacillus. The bacteriologic investigation of the water supply of farms has been continued and additional reports are now available. These show increased contamination, probably the result of spring rains and the warmer weather.

These studies have been found so interesting that the Secretary of Agriculture has ordered a repetition of the inspection of the 1,000 farms supplying Washington. This inspection will include a bacteriologic examination of the water supply of each farm. The Bureau of Public Health and Marine-Hospital Service examined bactericlogically 172 samples of milk during August and September, with an average of $22,134,259$ bacteria. The Department of Agriculture supplemented this work by examining 372 samples from October 27 to December 3, 1906, comparatively cool weather; and found an average of $97 \%, 315$. Recently the same department has examined 130 samples of ice cream. Five of these samples contained less than 500,000 bacteria to the cubic centimeter, the remainder ranged from over $1,000,000$ to $364,000,000$ per cubic centimeter. These figures draw attention to a most dangerous factor as a probable cause of disease.

The information obtained from these investigations conducted by these two great departments of the government, the Department of Agriculture and the Bureau of Public Health and Marine-Hospital Service, so impressed the District Commissioners that they, on March $30,190 \%$, addressed a letter to a number of prominent government officials and leading citizens inviting them "to confer with respect to the milk supply in the District of Columbia, and to advise them what further steps should be taken to improve it, especially with reference to the question of employing either certification of milk of standard excellence or the pasteurization of the District milk supply, or both, and what amendments should be made to the commissioners' bill for the better regu- 
lation of the milk business introduced in the last session of Congress."

On April 10 the men invited to this conference met and organized the Milk Commission with the following officers :

Chairman.-Gen. Geo. M. Sternberg, Surgeon General, U. S. Army, retired.

Vice Chairmen.-Dr. Harvey W. Wiley, Department of Agriculture, and Dr. Geo. M. Kober, Professor of Hygiene, School of Medicine, Georgetown University.

Secretary.-Dr. W. C. Woodward, Distriet Health Officer.

Several subcommittees were appointed.

Subcommittee on Infant Feeding: Chairman, Dr. Harvey W. Wiley, Chief of Bureau of Chemistry, U. S. Department of Agriculture; Gen. Geo. M. Sternberg, Dr. Stitt, U. S. Navy; Dr. J. W. Kerr, Asst. Surgeon General, Bureau of Publie Health and Marine-Hospital Service; Drs. D. P. Hickling, Wm. M. Sprigg, and W. C. Woodward.

Subcommittee on the Sanitary Condition of the Milk Supply: Chairman: Dr. Geo. M. Kober, Professor of Hygiene, School of Medicine, Georgetown University. His associates were Drs. A. D. Melvin, Chief of Bureau of Animal Industry, U. S. Dept. of Agriculture; M. J. Rosenau, Director of $\mathrm{Hy}$ gienic Laboratory, U. S. P. and M.-H. S.; John R. Mohler, Chief Pathologist, Bureau of Animal Industry, Department of Agriculture; Chas. T. Mason, Asst. Surgeon General, U. S. Army; G. Lloyd Magruder, E'meritus Professor of Materia Medica and Therapeuties, School of Hygiene, Georgetown University, together with Messrs. E. H. Webster, Chief of Dairy Division, Bureau of Animal Industry, Dept. of Agriculture, Col. Robert G. Smith, milk producer, and E. Berliner.

The matter assigned to these committees was divided into several subheads and was so carefully and exhaustively considered by men well versed on the subject that copious excerpts from the reports which were submitted to the full commission on April $1 \%$ and May 1 and unanimously adopted, are presented in abstract with the feeling that much of value will be given:

Extracts from the recommendations unanimously adopted by the committee to consider milk in relation to the food of infants:

1. The milk which is supplied to infants under the age of 3 years in the District of Columbia should be certified by the health officer, and should contain not more than 10,000 bacteria per cubic centimeter, should be not more than twelve hours old, and should be delivered in artificially cooled packages.

2. The bealth officer of the district should be authorized to 
advertise for dairies which will be willing to so modify their barns, stables, etc., if necessary, as to secure a license from him for the production of certified milk under the most modern improved sanitary conditions.

3. Each cow furnishing the milk in the dairy should be tested, under the supervision of the health officer, for tuberculosis or other contagious or infectious diseases, and that any animal so sufiering be excluded from the herd.

4. A daily sample, or samples, drawn from the supply of each certified milk furnished to the city should be secured for the purpose of making the bacterial count and determining the chemical composition, ete.

5. Parents and guardians should be urged to use only certified milk, at least for infants' food in the District of Columbia for all infants under the age of 3 years.

6. If private dairies can not be induced to furnish certified milk, the commissioners of the District of Columbia, as a health measure affecting in the highest degree tne welfare of the District of Columbia, should be asked, if it can legally be done, to establish a municipal dairy for the purpose of furnishing certified milk for the use of infants under 3 years of age in the District of Columbia.

7. For the purpose of securing modilied mi'k for infants in ill health, according to the prescription of physicians the Milk Commission of the District Medical Society should be requested to secure the establishment of a laboratory under its supervision in which only certified milk shall be used, and in which, by the use of a separator, or otherwise, milk of a definite chemical composition may be prepared from certified milk, in harmony with the physicians' prescriptions relating thereto,

10. The term "certified milk" as used herein is to be applied to milk secured at dairies subject to a periodic inspection, and the products of which are subjected to constant analysis. The cows providing the milk are to be properly fed, free of tuberculosis or other contagious diseases, and housed in clean stables, properly ventilated, and they are to be supplied with wholesome water and food, and kept clean. The milk is to be drawn under precautions to avoid infection, is to be immediately strained and cooled, and packed in sterilized bottles which are to be kept at a temperature of about 40 degrees $\mathrm{F}$. until delivered to the consumer.

\section{VARIOUS DISEASES AND CONDITIONS OF CATTIE THAT MAY AFFECT THE QUALITY OF THE MILK SUPPLY.}

BY JOHN R. MOHLER.

The importance of obtaining a hygienic and wholesome milk supply for the residents of this eity is recognized by all inteli:gent people and should require no argument. Public health 
demands the purity of all milk and milk products. Next to bread, milk is more extensively used as an article of diet than any other foodstuff. It forms a portion of the food of almost every person practically every day of the year. Moreover, unlike many other articles of diet, milk is consumed in most cases in an uncooked state, making it a very dangerous food should it perchance contain any deleterious organisms. The reasons for securing a supply of pure and wholesome milk are so numerous and so important that the consumer should become acquainted with some of the more essential of them in order that he may render assistance in bringing about a satisfactory improvement. Not only is milk a very suitable medium for almost every description of germ life which may gain access to it in its journey from the cow to the consumer, but it may also become contaminated while still in the udder through infectious or poisonous material present in the cow herself. Consideration in this report will be given only to the latter aspect of the question of a wholesome milk supply. In tnis connection it will be necessary to keep in mind the requirements of an awakened public for a clean and wholesome milk as well as the effect of any unreasonasle or irrational demand on the producer which may cause him heavy losses, or even to discontinue his business.

It will also be apparent from the report of the Committee on Sanitation that in order to produce milk in compliance with the requirements hereinafter to be described, certain precautions must be taken which will necessarily entail additional expense on the producer of this higher grade of milk. The customer must therefore expect to pay his portion of any legitimate advance in the cost of production, and such increase in the price of milk due to its improved quality should be considered as money well expended. Furthermore, we can not have good milk of safe quality without a realization on the part of the farmer, transportation agent, dairyman and housewife of the danger in utilizing old, warm or dirty milk. Education is an important factor, therefore, in the improvement of the milk supply which can not be accomplished through laws and regulations alone. In view of these facts it is recommended that the subject be taught in the schools, that popular articles be frequently prepared for the press, that lectures and demonstrations be given in towns and townships, that pamphlets in plain language be prepared by the Health Officers for general distribution, and especially that rules and suggestions. with reasons therefor, be placed in the homes of dairymen and dairy attendants.

MILK FROM UNHEALTHY COWS AS A FACTOR IN THE SPREAD OF DISEASE.

Tuberculosis.-Probably the most important disease of cows from the standpoint of public health is tuberculosis, and it is 
also the most prevalent. Notwithstanding the announcement of Koch that, in his opinion, tuberculosis in man and cattle is a different disease, it is now the generally accepted opinion among scientists that people, especially children, may become infected with tuberculosis from eattle. It is not known to what extent such infection occurs, nor is it possible to obtain any definite percentage by the method formerly adopted of looking for the primary lesions in the intestinal canal, although much statistical evidence is recorded, showing that even by these figures primary intestinal tuberculosis of children has been observed in as high as 45.5 per cent, of the tuberculous cases examined. (Heller.)

Evidence which must be considered conclusive has been obtained by the Bureau of Animal Industry as well as by Ravenel and a number of French investigators, showing that tuberculous infection may take place through the intestinal tract without leaving any lesion in the abdominal cavity, the first alteration being found in the lungs or thoracic glands. Therefore the presence of pulmonary tuberculosis in infants without intestinal lesions is no indication that the disease was not transmitted by the food, and the statistics above referred to are thus shown to be below the true percentage of eases of tuberculosis of intestinal origin. These figures, however, do not give any satisfactory idea as to whether the bacilli entering the intestines originated from human or bovine sources. Owing to this fact, it follows that the only way of determining the infection of people by bacilli of the bovine type will be to study the lesions in the body of as many cases of human tuberculosis as is possible.

The finding of the bovine type of tubercle bacillus in human lesions is the most direct and positive proof that tubereulosis of cattle is responsible for a certain amount of tuberculosis in the human family. Numerous experiments with this object in view have already proven this fact. Thus the German commission on tuberculosis examined 16 different cultures obtained from tubercular lesions in children and found four which were more virulent than is usual for human tubercle bacilli, causing tuberculosis in the cattle inoculated with them, and making 25 per cent. of the cases tested, affected with a form of tubereulosis which, by Koch's own method, must be classified as of bovine origin. In a similar series of tests conducted by the British royal commission on tuberculosis, 60 cases of the disease in the human were tested, with the result that 14 cases were claimed by this commission to have been infected from bovine sources. Ravenel reports that of 5 cases of tuberculosis in children, 2 received their infection from cattle.

Theobald Smith has also reported on one culture of the bovine tubercle bacillus obtained from the mesenteric glands of a child, out of 5 cases examined, and according to a recent 
paper by Goodale, Smith has recently been at work on 7 other cultures from different children, 4 of which conformed to his idea of tubercle bacilli emanating from cattle. Of 4 cases of generalized tuberculosis in children examined in the Biochemic Division of the Bureau of Animal Industry, 2 were found to be affected with very virulent organisms, which warranted the conclusion that such children had been infected from bovine source. The Pathological Division of the same bureau has likewise, out of the 9 cases of infantile tuberculosis examined, obtained two cultures of tubercle bacilli that could not be differentiated from bovine culture. In Europe so many similar instances of bovine tubercle bacilli having been recovered from human tissues are on record that it appears to your committee entirely proven that man is susceptible to tuberculosis caused by animal infections, and while the proportion of such cases can not be decided with even approximate accuracy, it is nevertheless incumbent on us to recommend such measures as will guard against these sources of danger, when enforced.

The two principal sources of infection from cattle and the only ones necessary to be considered are the meat and milk of tuberculous animals. The fact that most of the cases of bovine tuberculosis above enumerated which occurred in the human were cases of infantile tuberculosis points with grave suspicion to the milk rather than the meat supply. This naturally leads to the question of how and under what condition does the milk become infectious. That milk coming from a tuberculous udder is capable of transmitting the infectious principle is conceded by all who have given the subject any consideration. It has been equally established that in advanced generalized tuberculosis the udder may secrete tubercle bacilli without showing any indication of being affected.

Careful experiments performed by trained and eminently responsible investigators have also demonstrated beyond reasonable doubt that tubercle bacilli at certain times may be present in the milk of cows affected with tuberculosis to a degree that can be detected only by the tuberculin test, so that in a herd of cows in the various stages of tuberculosis it is to be expected that some of them will secrete tuberculous milk, which, when mixed with other cows' milk, makes the entire product dangerous. Even when the tubercle bacilli are not being excreted by the udder, it has been shown by Eber in Germany and Schroeder in this country, that the dust and manure of the stable where the diseased animals are kept are in many cases contarninated with tubercle bacilli.

In a recent examination of the manure passed by twelve cows just purchased from dairy farms in this eity and affected with tuberculosis to an extent only demonstrable by the tuberculin test, tubercle bacilli were found in over 41 per cent. of the cases both by microscopic examination and animal inoculations. The danger from this method of infecting milk is im- 
pressed on us as consumers when we realize that on an average probably 25 per cent. of all the eows which supply milk to the district are tuberculous, and this is considered to be a conservative estimate, judging from the results of recent tuberculin tests. Vital statistics show that 14 out of every 100 people that die succumb to tuberculosis, while of the remaining 86 more than one-half show lesions of tuberculosis on postmortem examination, although dying from some other cause...

The statement of von Behring above mentioned is particularly pertinent in regard to the relationship of human tuberculosis to the milk supply, and especially in connection with the results of those investigators who have studied market milk and found from 5.2 to 55 per cent. of the samples examined to contain tubercle bacilli. LeBlanc considers the milk of tuberculous cows dangerous even when bacilli are not present, on account of the toxin it contains. Michellazzi has injected such milk into tuberculous animals and obtained a reaction. To eliminate all tuberculous cattle from the herd, or to pasteurize all milk coming from untested cattle, should therefore be the object of all producers of milk and the sanitarians will be remiss in their whole duty should they neglect to guard against the products of tubereulous animals in their attempts to eradicate tuberculosis from man.

other Diseases.-Foot-and-mouth disease, anthrax, cow-pox, and rabies may be transmitted by the milk, and while no case of actinomycosis in man has been traced to the use of milk it is desirable that the use of milk of cows so affected should ve prohibited, especially when the disease affects the udder. Such conditions as gastroenteritis and septic and febrile conditions may render the milk injurious to the consumer. Local diseases of the udder like Botryomycosis, mammitis, mastitis, ete, may render the milk unwholesome, especially when pus organisms are present. The color, taste and odor of milk may be altered so as to make it unpalatable if not unwholesome; these changes may be due to the food of the cow or to bacterial changes in the milk after it is drawn from the udder. Milk may acquire poisonous properties from the food eaten by the cow. The milk produced shortly before or during the first five days after parturition should not be used.

Recommendations.-In view of the facts above enumerated, your committee desires to make the following recommendations:

1. All cows on dairy farms producing milk for the District of Columbia shall be tagged, tattooed or otherwise marked, for purpose of identification.

2. All milk produced on such dairy farms shall come either from tuberculin tested eattle, which shall be retested at least once a year, or be subjected to pasteurization under the supervision of the health department in case the herd is not tuberculin tested. 
3. No additions to any herd, whether tested or not tested, shall be made in the future without subjecting such cattle to the tuberculin test.

4. No license shall in future be granted except to applicants having herds free from tuberculosis.

5. The milk of cattle showing any of the udder affections above mentioned, anthrax, rabies, gastroenteritis, septic conditions or clinical symptoms of tuberculosis, shall not be utilized as human food, even though the milk be pasteurized. Milk from cows 15 days before and 5 days after parturition, and that from animals receiving any of the deleterious medicaments of foodstuffs previously mentioned shall likewise be excluded.

6. That the veterinary inspectors of the health department make frequent visits to dairies having untested herds, in order that they may discover all adranced cases of tuberculosis. or udder tuberculosis, as early as possible.

\section{MILK SEDIMENTS OR DIRTY MILK IN REIATION} TO DISEASE.

BY GEORGE M. KOBER, M.D.

Professor of Hygiene, School of Medicine, Georgetorn Lniversity.

Every consumer of milk has doubtless observed the presence of more or less foreign matter at the bottom of the bottle in which it is kept; indeed, it is a matter of such common oceurrence that it hardly excites our attention, and many are disposed to look on it as a matter of conirse. Professor Sox?let of Munich was perhaps the first to point out that these deposits are largely made up of the excrementitious matter from the cow, which adhering to the udder of the animal, gained access to the bucket during the act of milking.

If these sediments are subjected to microscopical examination we will find that they are composed of epithelial débris, hairs of the cow, organic and inorganic dust particles, excrementitious matter, vegetable fibers, bacteria, fungi and spores of every description; fully 90 per cent. of the germs are fecal bacilli-all of which is not only disgusting but extremely suggestive of danger. The number of micro-organisms is largely increased and we know that under a suitable temperature bacterial development and consequent decomposition are ma. terially hastened in such a medium. The greatest danger from milk of this class is the possible presence of ptomains or toxinproduced by certain saprophytic germs from the albuminoids of the milk.

The views of Vaughan. Booker, Escherich, Harrington, Kober and others on the relation of saprophytic germs and toxins to cholera infantum and the summer diarrhens in bottle-fed children are gaining ground and will doubtless lead to great reform in the management of dairies. It may be urgerl that all such modern innorations involve unnecessary hardship, but it 
should be remembered that by attacking all the rarious factors concerned in the causation of the disease we may hope for the best results. The reduction in the general mortality in the registration area of the United States from 19.6 in 1890 to 16.2 per 1,000 shows what may be accomplished by preventive medicine and sanitation.

Mill: in Relation to Infectious Discases.-Milk may acquire infective properties after it leaves the udder of the animal. Numerous instances have been observed in which outhreaks of typhoid fever, scarlet fever and diphtheria, by their sudden and explosive character, affecting families living in streets and localities supplied by the same milkman, naturally pointed to the milk supply as a common cause. Dr. Michael Taylor, however, was the first physician (in 1S5T) to point out definitely that cow's milk might serve as the medium of spreading typhoid ferer from a dairy where the disease prevailed. In 1867 he also showed that searlet fever might be distributed in the same way. In $1877 \mathrm{Mr}$. Jacob traced a diphtheria epidemic at Sutton to the milk supply and in 1S7: Mac Namara traced an outbreak of cholera at Calentta to an infected dairy. These facts could not fail to sharpen the powers of observation in others, so that in consequence similar outbreaks were more frequently reported. I was enabled to present to the International Nedical Congress held in Paris in 1900 the history of 195 outbreaks of typhoid ferer. ninety-nine of scarlet fever and six of diphtheria, all traceable to milk supply.

It has been demonstrated that disease germs may not only survive, but in many instances actually proliferate, in the milk. and it is not a difficult matter to point ont the many ways by which these germs gain access, especially when some of the employes are also engaged in nursing the sick, or are suffering themselves from some mild infection while continuing their duties. or are convalesent from the disease, and thus infect the milk m handling it.

After the reeital of numerous epidemies and milk-borne diseases. I need hardly insist on the necessity of empulsory nofifeation of all infections diseases, and that milk should not he permitted to leave a farm, dairy or milk-shop during the existence of any of these discases among the immates or employes nor shonld the latter be permitted to reside in or visit infected houses while engaged in the milk traffic withont permision from the health department. The farmer or retailer should, in fact. be prepared by previons instructions to guard the milk supply from these somrees of d:mger and call on the anthorities for an immediate inspection. To present great loss incident to thnse restrictions, they may be modified so as to use the milk after proper steriluzation under the direction of the health depratment. There is nothing strained in the requirements of the proposed legislation and by their enforeement we may hope to oldtain such a standard of milk as will 
not only eflect a decided reduction in infantile mortality, but will render the dissemination of infectious wiseases throug. 1 the milk supply a matter of history only. Until this is accomplished, we should patronize only such dealers as sell "certificd milk," or subject the milk to pasteurization, or simply bring the milk to the boiling point in the household, and, after cooling, keep it on ice; this will not make bad milk good, but it will at least destroy its infectiousness.

\section{SANITARY INSPECTION UF DAIRIES AND DIS- TRIBUTING DEPOTS.}

BY E. H. WEBSTER.

Chief of Dairy Division, Bureau of Animal Industry.

A systematic sanitary inspection of dairy farms and milkdistributing depots are anything but ideal; they are, in fact, about as bad as it is possible to conceive. Stables are poorly lighted, many having no windows whatever, and ventilation is left to care for itself. Little attention is paid to floors, ceilings, walks, or stable yards. Swine, horses and poultry are often found in the same barn with the cows. Manure is not removed, or, when removed, is thrown through. an opening in the wall or just outside the door, frequently near the milk room.

The necessary appliances for sterilizing and cooling in milk room are often lacking, making it impossible properly to wash and sterilize pails, cans, bottles and other appliances, or to properly cool and hold at a low temperature the milk before delivery. Milk dealers, as a rule, have more respect for sanitation and have better appliances than the average farm, but some common practices are deplorable. Very few have appliances for sterilizing bottles.

The situation in Washington is not diflerent from that confronting the health departments of most of the cities of any size throughout the country. The public is gradually awakening to the fact that these conditions must be changed. In oruer to bring about these changes within the district, it is recommended that:

1. A sufficient number of inspectors shall be employed so that each inspector shall have not over 100 farm dairies.

2. These men shall have technical training in the production and handling of milk.

3. The health officers shall have full authority to make rules and regulations, and to enforce the same, so as to safeguard the milk supply of the district from contamination through carelessness, ignorance or malicious intent.

4. The health officer, or any authorized inspector, shall have authority to revoke instantly the license or right to sell milk in the city if the provisions in these regulations are not complied with, where, in his judgment, such violation endange::s the health of the consumer. 
WATER SUPPIY OF DATRY FARMS.

BY G. LLOYD MAGRUDER, M.D.

Emeritus I'rofessor, Materia Medica and Therapeutics, sehool of Medicine, Georgetown Cniversity.

The influence of a polluted water supply has long been recognized as a most potent cause of disease. Many virulent epiuemics have been directly traced to this origin. The literature on this subiect is so full of instances that it is needless to cite additional examples. Immediate closure of such water supplies in cities, when sewage bacteria have been detected, has been universally recommended. The reent report to the District Commissioners by the Burean of Public Health and Marine-Hospital Service lays special stress on this point.

How much more is this danger augmented when such bacteria are found in the water supply of the dairy farms. It is well known that few farms have the proper facilities for boiling the water that is lised for washing the hands of the employer, the dairy utensils and the udders of cows. Such water readily contaminates the milk. which contamination is rapidly increased by the multiplieation of the bacteria when the temperature is above $50 \mathrm{~F}$.

In view of the possible presence of the bacilli of typhoid ferer and tuberculosis, the question of sewage bacteria in the water sapplies of the dairy farms is a much more serious matter than was formerly considered. The knowledge that iyphoid ferer was $21 / 2$ times more prevalent in 1906 in the counties of Maryland than in the eity of Baltimore, and the cridence, as stated elsewhere in this report that 148 out of 195 epidemies of typhoid fever attributed to milk were directly traced to the dairy farm, adds to the serionsness of these conditions.

It has been observed that many wells, springs and eisterns are loosely or not at all covered, poorly protected from surface drainage, and, in mumerous cascs, are located in close proximity to the barnyard or to the lousehold privy, at times even in places that eateh the drainage from the same.

The examinations made by officials of the Department of Agriculture during Yovember and December, 1906, in comparatively cool weather, showed that, of the 60 water supplies of dairy farms taken at random in Maryland, Virginia and the District of Columbia, 16 contained less than 500 bacteria per eubic centimeter and were free from lacillus coli-(i below this number contained the colon bacillus. The remaining 44 water suplies contained bacteria up to 27.200 . Of these 44,21 rontained the eolon bacillus.

These tests warranted the classification of these water supplies as follows: 16 good, 15 fair, 17 suspicious, and 12 unfit for use. Fromi Professor Sedgwick's classification 44 would have been ennsidered polluterl. In a recent letter he says: "I 
should say that all of the wells under consideration which had more than 100 bacteria per cubic centimeter were to be classed as suspicious, and that those having 500 or over were, in all probability, polluted."

The results of those examinations confirm the wisdom of the recommendation made in 1894 by the committee of the Medical Society of the District of Columbia on the prevalence of typhoid fever, for the careful inspection of all dairy farms for all possible sources of infection, including the water supply, and prove that repeated chemical and bacterial tests should be made of the water supplies of every dairy farm supplying milk to the Cicy of Washington. They afford another proof of the imperative need of a well-equipped chemical and bacteriological laboratory for the Health Officer.

Fortunately, many of these insanitary conditions on the farm can be readily and easily remedied by the farmer himself, by the exercise of a little care and at a very trifling cost.

All water, except that above suspicion, used for dairy purposes should be boiled. Those engaged in the handling of dairy products should be required to observe the greatest eare as to the cleanliness of their clothes and person. Frequent washing of their hands should be practiced. The source of the water supply should be at least fifty feet from any possible infection, and a greater distance if in line of drainage from any infection.

The wells, springs and cisterns should be carefully walled and covered to protect them from seepage, drippings and dust. A well-built coping, extending a foot or more above the ground would be very effectual. Preferably deep driven wells should be used when possible. Owing to the inclination of the rock formation in this vicinity, these are not always absolutely reliable. When a water supply is found to be polluted, it should be thoroughly cleaned and properly disinfected.

All fecal discharges should be deposited in a safe place, and those from fever cases in addition should be intelligently disinfected. Since freezing does not immediately kill bacteria, careful supervision shound also be observed over the supply of water for and the location of ice ponds from which ice is obtained for household and dairy purposes. By observing these simple precautions, which would in no way be a hardship to the producers, much would be accomplished toward securing a better milk suppply.

The series of check experiments conducted during September, October and November, 1906, by the Department of Agriculture and those in charge of the filtration plant, demonstrated its efficiency as a safeguard against typhoid infection from the Potomac River. The report of the examinations of the Potomac Water Supply for March confirms the deduction heretofore made. 


\title{
COMMERCIAL CLASSES OF MILK.
}

\author{
BY A. D. MELVIN. M.D.
}

Chief of the Bureau of Animal Industry.

In view of the elaborate manner in which the necessity for a pure milk supply has been pointed out, and of the many obstacles in the way of obtaining such a suppiy except through vigorous official supervision, it is believed that if the milk supply is divided into three classes as hereinafter described, and an efficient supervision provided, the consumer will be amply protected in securing clean and uncontaminated milk, therefore the following recommendations are respectfully submitted:

That the milk supply of the city be divided into three classes, to be known as Classes 1, 2 and 3. The specifications for certified milk for infants to be the same as recommended by the Milk Commission, and to be known as Class 1.

Class 2 to be clean, raw milk from healthy cows as determined by the tuberculin test and veterinary physical examination. The cows to be housed, fed and milked under good conditions. but not neeessarily equal to the conditions prorided for Class 1. Pure water as determined by chemical and bacteriologic examination, to be provided and the bacteriologic count of the milk not to exceed 100,000 bacteria per c.c., at the time the milk reaches the city, at any season of the year, and determined by the health department at frequent intervals. Milk to be delivered to the consumer in sterilized containers to be filled on the dairy farm and the temperature of the milk not to exceed $50 \mathrm{~F}$. until delivered to the consumer.

Class 3 to be milk from all other dairies not able to comply with the requirements for Classes 1 and 2 . This milk to be clarified and pasteurized at central pasteurizing plants which shail be under the personal supervision of an officer of the health department. These pasteurizing plants may be provided by either private enterprise or by District government, and shall be located within the city of Washington. Class 3 milk shall not be permitted to exceed $60 \mathrm{~F}$. in delivery from the dairy to the pasteurizing plants. The milk from these pasteurizing plants, placed in sterilized containers, shall be delivered to the consumer at a temperature not exceeding 50 F. All milk of unknown origin shali be placed under Class 3 and subjected to clarification and pasteurization. It is also provided that no cows suffering from any communicable disease, or any unfit condition to be determined on physical examination by an authorized veterinarian, shall be permitted in any dairies. It is further provided that cows which do not show any physical signs of tuberculosis on veterinary examination, but which may have reacted to the tuberculin test, may be included in dairies supplying milk of this class.

No dairy farm shall be permitted to supply milk of a higher class than the class for which the permit has been issued and each dairy farm supplying milk of a specified class shall be 
separate and distinct from any dairy farm of a different class; the same owner, however, may supply different classes of milk. providing the dairy farms are separate and distinct, as above indicated. All milk to be of good composition, free of adulterants and artificial coloring matter. The term "milk" to include both milk and cream.

\section{PASTEURIZATION.}

BY M. J. ROSENAU, M.D.

Director Hygiene Laboratory, U. S. P. H. and M.-H. S.

Advantages.-The advantage of pasteurization is that it is a cheap and effective means of preventing the transmission of infectious diseases such as tuberculosis, typhoid fever, diphtheria, scarlet fever, etc., commonly spread by milk.

Disadvantages.-1. Pasteurization promotes carelessness on the farm and dairy, etc. (This may be controlled by proper regulations, inspections and laboratory examinations.)

2. Pasteurization renuers milk less digestible. (While it is generally conceded that boiled milk commonly induces constipation, the majority of the evidence plainly indicates that pasteurization has little, if any, effect on the digestibility of the milk.)

3. Pasteurized milk favors the production of rickets and scurvy. (There is no proof to this effect and authorities agree that the danger is slight; and, further, that it may readily be obviated.)

4. By destroying the non-spore-bearing bacteria, pasteurization sometimes allows toxic organisms to grow and produce serious poisons in the milk. (On the other hand, these same poisons are more trequently produced in milk that has not been pasteurized, and this danger may be obviated in pasteurized milk by cooling it quickly, keeping it cold and shortening the time for distribution.)

5. Pasteurization is inefficient as a preservative; the milk keeps only 12 to 24 hours longer than otherwise. (This is really no disadvantage, for the quicker bad milk sours, the better.)

6. Pasteurization injures the taste of the milk. (This is not so, if properly done.)

7. Pasteurization inereases the cost of the milk. (True, but it is the cheapest safeguard, and the expense of pasteurization is offset by the keeping quality of the milk.)

Methods.-The milk must be heated to a temperature of 65 C. (149 F.) for 20 minutes, or 70 C. (158 F.) for $10 \mathrm{~min}$ utes, as soon as practicable after the milking, in enclosed vessels, preferably the final containers. After pasteurization, the milk must be promptly cooled, kept cold and distributed with promptness.

The advantages so far outweigh the disadvantages that I unliesitatingly recommend compulsory pasteurization of all milk not certified under class 1 and Class 2 of Dr. Melvin's classi. fiention. 
Hollinger Corp. pH 8.5 